\title{
Endogenous purine and pyrimidine derivative excretion in pregnant sows
}

\author{
BY S. M. MARTIN ORUE, J. BALCELLS, J. A. GUADA AND C. CASTRILLO \\ Departamento de Producción Animal y Ciencia de los Alimentos, Facultad Veterinaria, Miguel Servet \\ 177, Zaragoza 50013, Spain
}

(Received 7 October 1993 - Revised 20 April 1994 - Accepted 7 July 1994)

\begin{abstract}
The present experiment was carried out to study the endogenous losses of purine and pyrimidine derivatives from pregnant sows. Three pregnant and three non-pregnant Large White $\times$ Landrace sows were fed on a purine-free diet composed of starch, glucose, sucrose and vegetable oil, with casein as the protein source. The experiment began, for the six animals, after diagnosis of pregnancy and was divided into six $12 \mathrm{~d}$ periods. Urine was collected during the first $3 \mathrm{~d}$ of each experimental period by means of a urethral catheter for determination of allantoin, uric acid, xanthine, hypoxanthine and pseudouridine concentrations. In the absence of dietary nucleic acids (NA), allantoin and, as a consequence, excretion of total purine derivatives (PD) decreased significantly to a constant value (128.3 (SE 7.07) $\mu \mathrm{mol} / \mathrm{kg}$ metabolic live weight $\left(W^{0.75}\right)$ per $\left.d\right)$, an amount assumed to represent endogenous excretion. Excretion of uric acid (38.7 (SE 2.15) $\mu \mathrm{mol} / \mathrm{kg} \mathrm{W}^{0.75}$ per d), hypoxanthine (21.0 (SE 2.58) $\mu \mathrm{mol} / \mathrm{kg} \mathrm{W}^{0.75}$ per d) and xanthine (11.2 (SE 0.83) $\mu \mathrm{mol} / \mathrm{kg} \mathrm{W}^{0.75}$ per d) were not affected by the experimental treatment, although there was a significant decrease in hypoxanthine excretion in pregnant sows (from 25.5 to $5.2 \mu \mathrm{mol} / \mathrm{kg}$ $W^{0.75}$ per d) compared with non-pregnant sows (from 26.7 to $44.8 \mu \mathrm{mol} / \mathrm{kg} \mathrm{W}^{0.75}$ per d). Creatinine excretion was not affected by pregnancy and was used as an internal urinary marker. Purine excretion, either expressed as $\mu \mathrm{mol} / \mathrm{kg} \mathrm{W}^{\mathbf{0 7 5}}$ per $\mathrm{d}$ or as the ratio PD: creatinine, was not affected by experimental treatment, although an apparent increase in pseudouridine excretion, a modified unsalvageable catabolite of RNA-pyrimidine, was found in late pregnancy (3.6 v. $5.2 \mathrm{~mol} / 100 \mathrm{~mol}$ creatinine in non-pregnant sows compared with pregnant sows at $102 \mathrm{~d}$ collection).
\end{abstract}

Purine derivatives: Pseudouridine: Pregnancy: Sow

Metabolism of nucleic acids (NA) involves a substrate cycle whereby nucleotides are degraded continuously to nucleosides and free bases which are subsequently salvaged for re-synthesis of new nucleotides (Murray, 1971). However, this NA turnover is not fully efficient, generating, as a consequence, endogenous losses which constitute an important fraction of the total urinary excretion of purine derivatives (PD). These endogenous losses, measured as urinary PD excretion when there is no exogenous NA supply, have been measured in single-stomached animals fed on purine-free diets (Greife, 1980; Chen et al. $1990 \mathrm{~b}$ ), in preruminants maintained on a purine-free liquid diet (Lindberg, 1991) and in ruminants, either by avoiding rumen fermentation (Ørskov et al. 1979; Chen et al. 1990 b) or by substituting duodenal flow for a purine-free solution (Balcells et al. 1991).

In previous reports, changes in nutritional status, i.e. protein (Fujihara et al. 1987) or energy supply (Giesecke et al. 1984; Lindberg \& Jacobsson, 1990), had little effect on endogenous excretion of PD. However, there is a lack of information about the variations in endogenous losses in relation to different physiological states, and how these variations must be taken into account in order to establish the relationship between duodenal supply and urinary excretion of PD. On the other hand, pseudouridine is one of the most 
important modified transfer RNA (tRNA) and ribosomal RNA (rRNA) nucleosides which, after RNA-chain degradation, cannot be salvaged and is obligately excreted in urine. Urinary excretion of pseudouridine has been suggested as a RNA-turnover marker (Schöch et al. 1982) and, further, as a marker of protein synthesis if it is assumed both processes are linked (Sander et al. 1986a).

In the present study endogenous excretion of PD and pseudouridine were measured in non-pregnant sows and pregnant sows throughout pregnancy. A preliminary report of some of the results has been made by Martin et al. (1993).

\section{MATERIALS AND METHODS \\ Animals and feeding}

Six Large White $\times$ Landrace sows with an initial parity of four farrowings were used. Three of them (210 (SD 15) $\mathrm{kg}$ live weight) were mated and, after a positive pregnancy diagnosis (30 d after mating), these and the remaining three non-pregnant sows (220 (SD 7.2) $\mathrm{kg}$ live weight) were fed on a semi-synthetic NA-free diet ( $3 \mathrm{~kg}$ fresh matter $/ \mathrm{d}$ ) containing (relative proportions) maize starch $(0 \cdot 27)$, glucose $(0 \cdot 27)$, sucrose $(0 \cdot 20)$, vegetable oil $(0.04)$, casein $(0 \cdot 08)$, dicalcium phosphate $(0 \cdot 03)$, straw (ground at $3 \mathrm{~mm})(0 \cdot 10)$, methionine + threonine $(0.003)$ and a vitamin-mineral mixture (0.007). Vitamins and minerals were included at levels recommended by the Agricultural Research Council (1981).

The experimental diet analysed from weekly samples contained $920 \mathrm{~g} \mathrm{DM} \mathrm{kg}$ with the following composition $(\mathrm{g} / \mathrm{kg} \mathrm{DM})$ : organic matter 957 , protein $(\mathrm{N} \times 6.25) 80.4$, diethyl ether extract 58 , crude fibre 56 . The diet contained $19 \mathrm{mg}$ adenine and $25 \mathrm{mg}$ guanine $/ \mathrm{kg} \mathrm{DM}$ and 14.63 MJ estimated metabolizable energy $/ \mathrm{kg} \mathrm{DM}$ calculated on an as-fed basis. Animals were fed twice daily ( 08.30 and 15.30 hours) and kept in individualstall-housing with free access to drinking water.

\section{Experimental design}

The experiment began after diagnosis of pregnancy, with a gradual substitution of a commercial diet by the experimental diet over $4 \mathrm{~d}$. Urinary collection started $8 \mathrm{~d}$ later for three consecutive days using a Foley catheter (Folatex; $28 \mathrm{~mm}, 10 \mathrm{ml}$ balloon) inserted into the bladder. The same collection procedure was repeated every $12 \mathrm{~d}$ until parturition, giving a total of six collection periods. All animals were weighed twice, in the preexperimental period and at the beginning of the experiment, while non-pregnant sows were also weighed at the end of the experiment.

\section{Sample preparation and chemical analyses}

Daily total urine excretion was collected over $1 \mathrm{M}-\mathrm{H}_{2} \mathrm{SO}_{4}$ (final $\mathbf{p H}<3$ ). Urine weight and specific gravity were recorded and four subsamples $(0.3 \%$ of total) were stored immediately at $-20^{\circ}$ until analysed. Urinary allantoin, uric acid, hypoxanthine and xanthine were analysed by reversed-phase HPLC, using two Spherisorb C-18 ODS-5 $(4.6 \times 250 \mathrm{~mm})$ columns, according to the technique described by Balcells et al. (1992). Pseudouridine from urine, and adenine and guanine from feed samples were also analysed using the technique described previously. Before analysis, feed samples $(250 \mathrm{mg})$ were hydrolysed for $1 \mathrm{~h}$ at $100^{\circ}$ with $6 \mathrm{ml} 1.7 \mathrm{M}$-perchloric acid-0.1 mM-Allopurinol followed by immediate neutralization with $4 \mathrm{M}-\mathrm{KOH}$. Retention times for pseudouridine in urine samples and adenine and guanine in feed samples were $11 \cdot 0,13.5$ and $18.0 \mathrm{~min}$ respectively, with the three compounds showing a similar chromatographic behaviour to that described in the original technique. The average recovery of standards added to urine was in the order of $90 \%$ and the day- 
to-day variability was $<10 \%$. Pseudouridine was not detected in feed samples. Creatinine was analysed using a Technicon RA-500 with a picric acid reaction (Technicon Instruments Co. Inc. 1989).

\section{Calculation and statistical analysis}

Data were subjected to a factorial analysis of variance, with animals within physiological stages as the main plot and collection period as the subplot (Steel \& Torrie, 1980). An orthogonal set of contrasts over collection time was used to compare treatment means. All calculations were made using the BMDP (1990) package.

\section{RESULTS}

Animals remained in good health throughout the experiment, consuming all the experimental diet. However, one of the pregnant sows aborted ( $54 \mathrm{~d}$ after mating) and the experimental procedure was subsequently repeated with the same animal. Mean period of gestation was $116(\mathrm{SE} 0.7) \mathrm{d}$, and litter sizes were nine, fourteen and twelve piglets respectively for each sow. Mean birth weight, recorded $3 \mathrm{~h}$ post-farrowing when piglets were clean and dry, was 1.6 (SE 0.06) kg. The weights of the sows remained constant during the gradual substitution of the commercial diet, and in non-pregnant sows throughout the experimental period. All variables were related to initial body weight.

\section{Purine-derivative excretion}

Daily excretion for individual PD and the statistical significance of treatment effects are shown in Table 1. Allantoin excretion decreased significantly following dietary exclusion of purines, from previous values of 401 (SE 40.7) $\mu \mathrm{mol} / \mathrm{kg}$ metabolic live weight $\left(\mathrm{W}^{0.75}\right)$ per $\mathrm{d}$ to a mean level of 128.3 (SE 7.07) $\mu \mathrm{mol} / \mathrm{kg} \mathrm{W}^{0.75}$ per $\mathrm{d}$. However, the purine-free diet did not affect the urinary excretion of allantoin precursors, with means of 38.7 (SE 2.15), 11.2 (SE 0.83) and 21.0 (SE 2.58) $\mu \mathrm{mol} / \mathrm{kg} \mathrm{W}^{0.75}$ per $\mathrm{d}$ for uric acid, xanthine and hypoxanthine respectively. The mean excretion of total endogenous PD was $199 \cdot 2$ (SE 9.23) $\mu \mathrm{mol} / \mathrm{kg} \mathrm{W}^{0.75}$ per $\mathrm{d}$ with relative amounts of allantoin, uric acid, xanthine and hypoxanthine of 64 (SE 1.3), 19 (SE 0.8), 6 (SE 0.3) and 11 (SE 1.3)\%.

There were no differences in total endogenous PD excretion between pregnant sows (197.5 (SE 13.77) $\mu \mathrm{mol} / \mathrm{kg} \mathrm{W}^{0.75}$ per d) and non-pregnant sows (200.9 (SE 12.68) $\mu \mathrm{mol} / \mathrm{kg} \mathrm{W}^{0.75}$ per d), reflecting the constant excretion levels of the main PD (allantoin, uric acid), although hypoxanthine excretion, as salvageable PD, decreased significantly $(P<0.005)$ through pregnancy (from 25.5 to $5.2 \mu \mathrm{mol} / \mathrm{kg} \mathrm{W}^{0.75}$ per d).

Significant variations $(P=0.05)$ in $\mathrm{PD}$ excretion (particularly in allantoin $(P=0.05)$, uric acid $(P=0.03)$ and xanthine $(P=0.02))$ during the experimental period were detected which were independent of the physiological status. In order to avoid errors associated with possible urinary losses through the catheter urinary excretion was corrected using creatinine as an internal marker. Mean amounts of PD relative to creatinine excretion (PD: creatinine) are shown in Fig. 1. This method of expression reduced residual variation (coefficient of variation (CV) $27.8,22.5,37.3$ and $49.0 \%$ for daily excretion, compared with $19 \cdot 9,19 \cdot 2,27 \cdot 8$ and $48 \cdot 5 \%$, for the ratios of allantoin, uric acid, xanthine and hypoxanthine to creatinine respectively). When corrected for creatinine excretion the variation in PD excretion in relation to the experimental period remained significant $(P=0.05)$.

As stated previously, allantoin:creatinine, uric acid:creatinine and xanthine:creatinine values were not modified by pregnancy (constant mean values were 12.3, 3.7 and $1.0 \mathrm{~mol} / 100 \mathrm{~mol}$ creatinine respectively), whereas hypoxanthine:creatinine showed a different pattern $(P<0.005)$, decreasing in pregnant animals. Orthogonal contrasts showed 


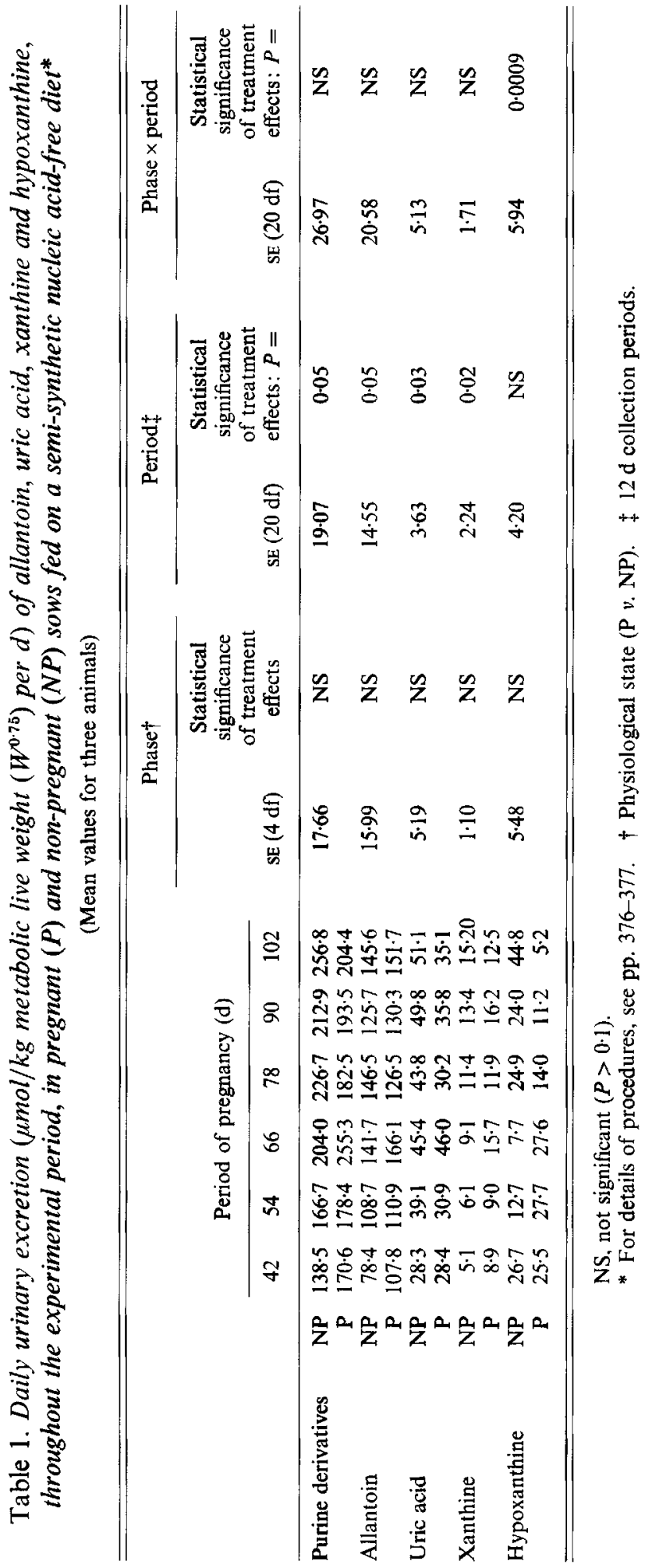




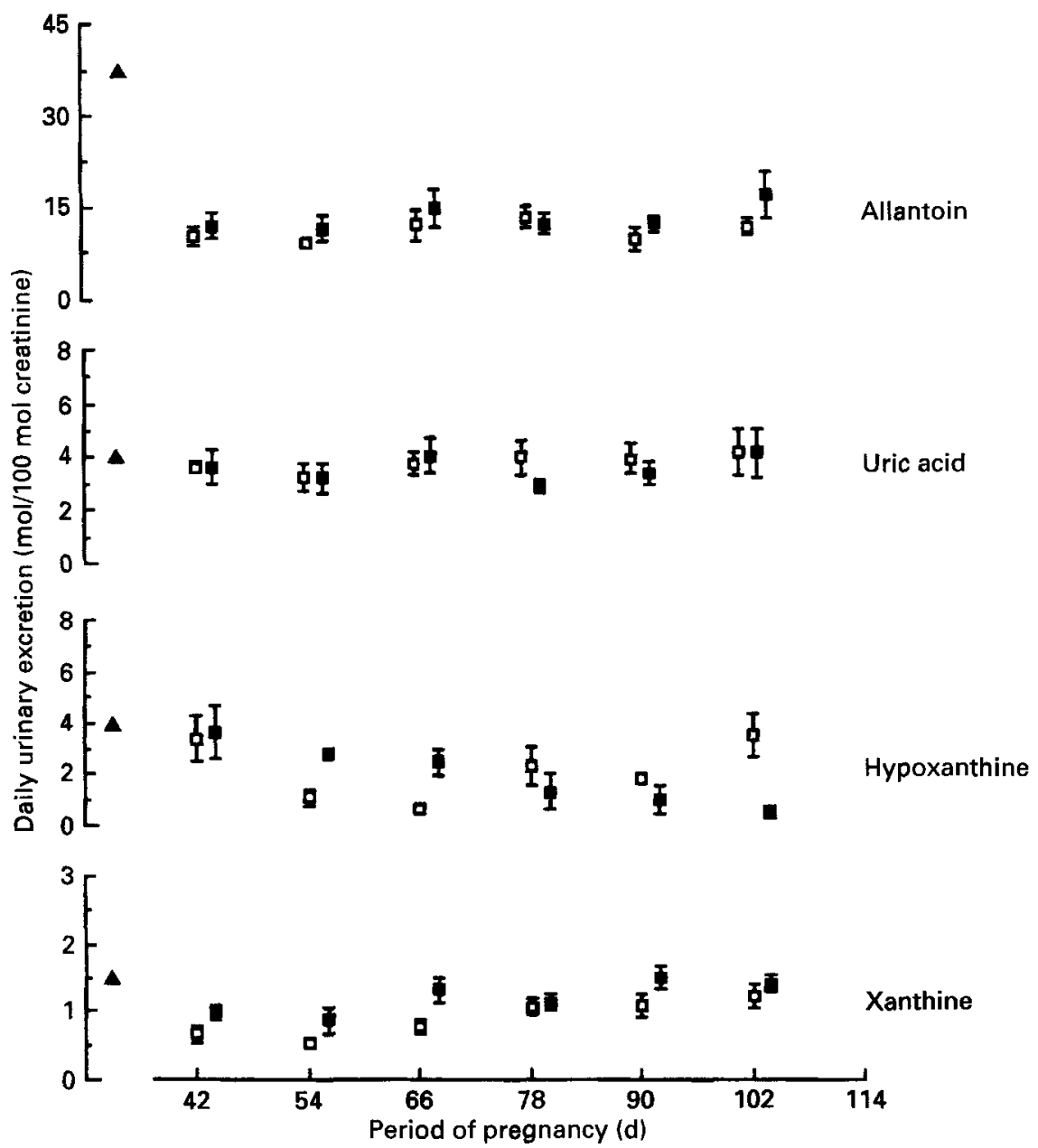

Fig. 1. Daily urinary excretion ( $\mathrm{mol} / 100 \mathrm{~mol}$ creatinine) of allantoin, uric acid, xanthine and hypoxanthine throughout the experimental period, and their pre-experimental levels $(\mathbf{A})$, in pregnant $(\square)$ and non-pregnant $(\square)$ sows fed on a semi-synthetic nucleic acid-free diet. Values are means and standard deviations represented by vertical bars for three animals. For details of procedures, see pp. $376-377$.

a lower ratio in the last two collection periods (90-102 d collection compared with 42-90 d collection $(P=0.009)$, and 90-102 d collection compared with $42-78 \mathrm{~d}$ collection $(P=$ $0 \cdot 014)$ ).

\section{Pseudouridine}

Mean excretion of pseudouridine, as a non-salvageable pyrimidine derivative, is presented in Table 2, expressed as $\mu \mathrm{mol} / \mathrm{kg} \mathrm{W}^{0.75}$ per $\mathrm{d}$ or as pseudouridine:creatinine ( $\mathrm{mol} / 100 \mathrm{~mol}$ creatinine). Fig. 2 shows the changes in pseudouridine:creatinine throughout the experimental period compared with that of total PD:creatinine.

The absence of dietary NA stimulated a decline in pseudouridine excretion followed by a further recovery until the $66 \mathrm{~d}$ collection to reach a mean value of 36.0 (SE 2.04) $\mu \mathrm{mol} / \mathrm{kg} \mathrm{W}^{0.75}$ in the experimental period without differences between physiological status. However, when expressed as $\mathrm{mol} / 100 \mathrm{~mol}$, creatinine showed a tendency to 


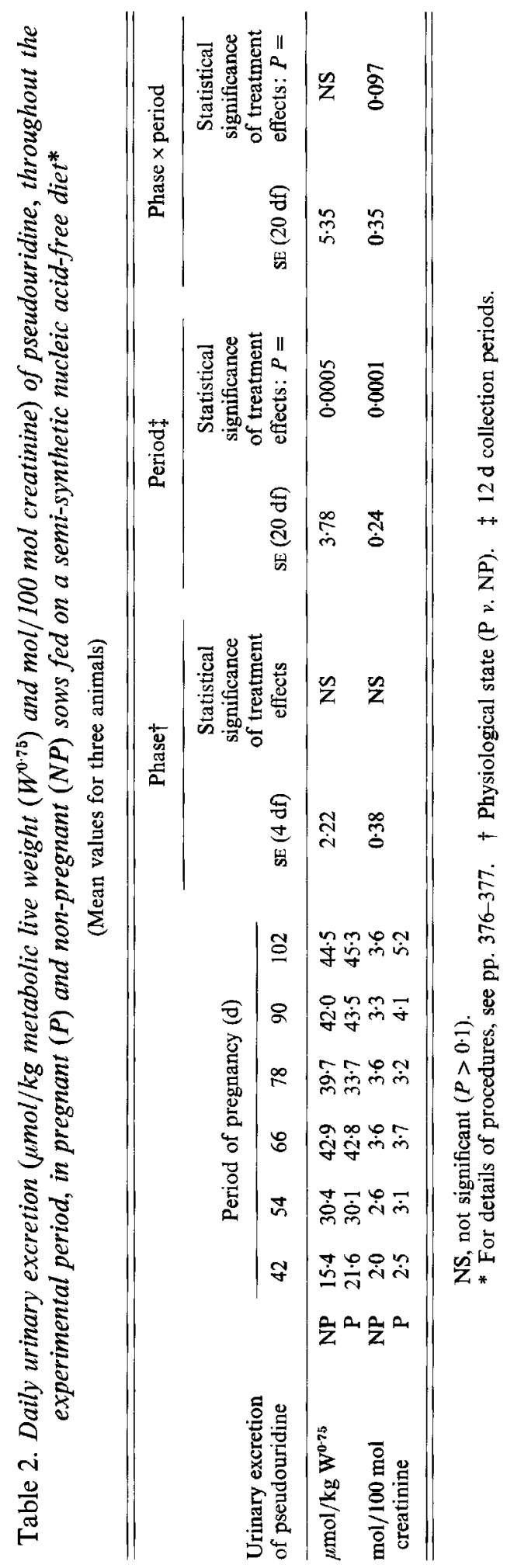




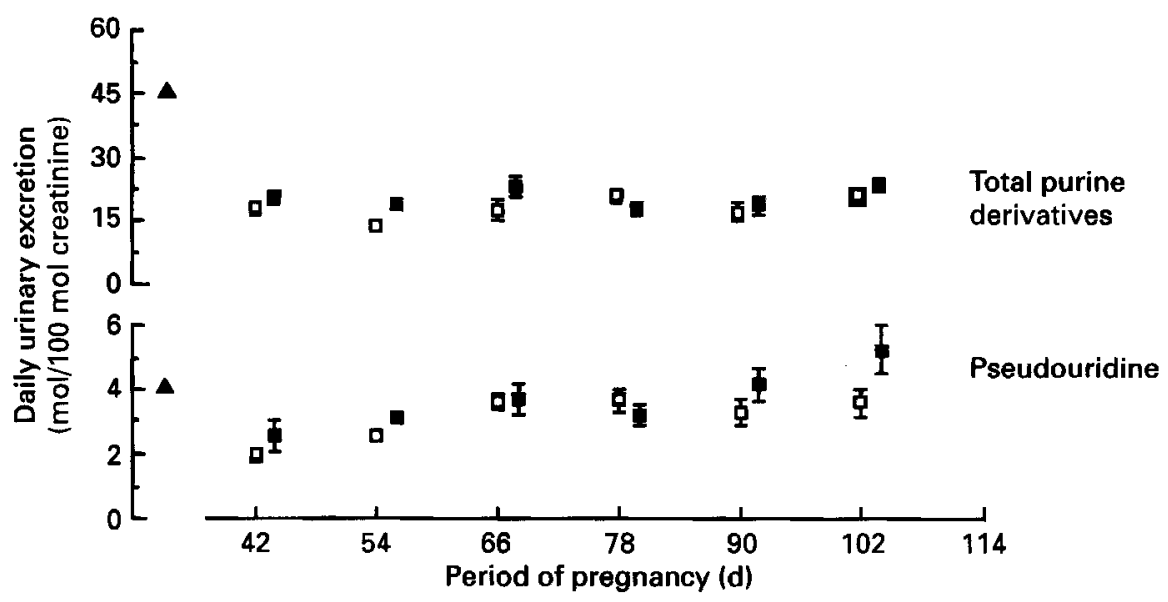

Fig. 2. Daily urinary excretion of total purine derivatives and pseudouridine ( $\mathrm{mol} / 100 \mathrm{~mol}$ creatinine) throughout the experimental period, and their pre-experimental levels $(\boldsymbol{A})$, in pregnant $(\square)$ and non-pregnant $(\square)$ sows fed on a semi-synthetic nucleic acid-free diet. Values are means and standard deviation represented by vertical bars for three animals. For details of procedures, see pp. 376-377.

continue onwards with pregnant animals whereas non-pregnant animals maintained a constant value as shown. This effect was apparent $(P=0.097)$ when values were related to creatinine excretion and also when the last period ( $90-120 \mathrm{~d})$ was compared with previous collection periods $(P=0.086)$.

\section{DISCUSSION}

Many recent studies have investigated the origin and significance of PD and pyrimidine derivatives excreted in urine, usually by measuring the endogenous fraction after avoiding the flow of dietary NA to the duodenum. The same procedure was followed in the present study, maintaining the animals on a NA-free diet during pregnancy, to compare endogenous losses of pregnant and non-pregnant sows.

In order to avoid differences in feeding level, assuming a certain presence of NA in the diet, which could mask variations in urinary excretion of purine and pyrimidine derivatives, both groups of animals were fed on the same amount of diet. The fact that non-pregnant animals kept a constant body weight throughout the experiment suggested a possible restriction on pregnant animals; however, the effect of moderate variations in energy and protein supply on endogenous excretion seems to be negligible (Giesecke et al. 1984; Fujihara et al. 1987; Lindberg \& Jacobsson, 1990).

\section{Endogenous excretion of purine derivatives}

Dietary absence of NA was followed by a rapid, significant decrease in allantoin and, consequently, total PD excretion; the latter reached a basal level of $199 \cdot 2$ (SE 9.23) $\mu \mathrm{mol} / \mathrm{kg} \mathrm{W}^{0.75}$ per $\mathrm{d}$ which is considered the endogenous fraction of the total urinary excretion. Uric acid, hypoxanthine and xanthine excretion remained unaffected by the experimental treatment. The consistency in the rate of urinary excretion of these allantoin precursors is in agreement with findings from previous studies on ruminants (Fujihara et al. 1988; Balcells et al. 1991, 1993), although a progressive increase in allantoin precursors, mainly uric acid, in response to duodenal purine input, have been reported for both single-stomached animals (Roth \& Kirchgessner, 1979) and ruminant animals (Chen 
et al. $1990 \mathrm{a}$ ). Although uric acid precipitation in urine samples cannot be fully excluded we could not find any differences when PD and pyrimidine derivatives were analysed in fresh samples or after collection and storage $\left(-20^{\circ}\right)$ below $\mathrm{pH} 3$.

Exogenous PD coming from absorbed diet precursors are carried by the portal vein to the liver, which constitutes the main site of degradation to allantoin due to the high activities in this organ of xanthine oxidase $(E C 1.1 .3 .22)$ and uricase $(E C 1.7 .3 .3$; alKhalidi \& Chaglassian, 1965; Chen et al. $1990 \mathrm{~b}$ ), key enzymes in purine catabolism. Thus, it can be expected that an increase in duodenal PD absorption would be recovered as urinary allantoin. Although extrahepatic cells contain trace amounts of xanthine oxidase and uricase (al-Khalidi \& Chaglassian, 1965), they may degrade a low but significant amount of endogenous NA, allowing disposal of salvageable catabolites by the kidneys without being transported to the liver. This might explain the constant fraction of endogenous allantoin precursors in the physiological urine.

The endogenous excretion of PD observed in the present study agreed well with the values reported by Chen et al. $(1990 \mathrm{~b})$ in growing pigs fed on a similar diet (166 $\mu \mathrm{mol} / \mathrm{kg} \mathrm{W}^{0.75}$ per d), or those of $164,168,190$ and $202 \mu \mathrm{mol} / \mathrm{kg} \mathrm{W}^{0.75}$ per $\mathrm{d}$ reported by Fujihara et al. (1987), Chen et al. (1990 b), Balcells et al. (1991) and Giesecke et al. (1984) respectively in sheep. The higher values observed in steers $\left(443-468 \mu \mathrm{mol} / \mathrm{kg} \mathrm{W}^{0.75}\right.$ per d; Fujihara et al. (1987)) and cows $\left(514 \mu \mathrm{mol} / \mathrm{kg} \mathrm{W}^{0.75}\right.$ per d; Chen et al. $(1990 \mathrm{~b})$ ) reflect the wide tissue distribution of xanthine oxidase activity (al-Khalidi \& Chaglassian, 1965). Uric acid excretion in humans, as the endproduct of purine metabolism, was $123.8 \mu \mathrm{mol} / \mathrm{kg} \mathrm{W}^{0.75}$ per d (Folin et al. 1924) or $2.87 \mathrm{mmol} / \mathrm{d}$ (Zöllner, 1982) but Greife (1980) reported a much higher value for allantoin plus uric acid excretion in rats $\left(130 \mu \mathrm{mol} / \mathrm{d}\right.$ or $969 \mu \mathrm{mol} / \mathrm{kg} \mathrm{W}^{0.75}$ per d) probably due to the higher rates of body protein turnover in this species (Waterlow, 1984).

Earlier work by Condon et al. (1970) showed that sheep receiving a standard supply of exogenous purines incorporated into their NA labelled purines infused duodenally in preference to labelled glycine, the main precursor of the 'de novo' pathway. Later studies confirmed the significance of the salvage process on the metabolism of PD in sheep (Smith et al. 1974; Razzaque et al. 1981), and models developed recently to estimate duodenal flow of PD in ruminants (Chen et al. $1990 \mathrm{a}$; Balcells et al. 1991) suggest that endogenous losses could be replaced by 'de novo' synthesis as the basis to the absence of response in PD excretion at the low levels of exogenous purine input. This assumption, however, needs to be demonstrated experimentally given that a simple purine-pool depletion cannot be excluded.

From our results the pattern of endogenous losses during the experimental period seems to preclude a depletion of the organic purine pool, suggesting constant replacement of the endogenous losses by 'de novo' synthesis. It should be pointed out that purine analysis of the experimental diet showed a negligible contribution by the exogenous purine supply, i.e. a maximum of $16.5 \mu \mathrm{mol} / \mathrm{kg} \mathrm{W}^{0.75}$ per $\mathrm{d}$, assuming total digestion of dietary straw purine.

Endogenous synthesis balanced the purine pool in non-pregnant sows and, in addition, was able to supply enough substrate to allow the growth of the gravid uterus. However, the probable increase in metabolic activity and purine synthesis during pregnancy was not reflected in the endogenous excretion level (Fig. 2). In contrast to our results, in a study on the effect of a continuously-altered $\mathrm{N}$ balance on the endogenous PD excretion using intragastric-fed animals, Chen (1989) reported a significantly higher endogenous excretion in pregnant ewes than in non-pregnant ewes.

There is a significant increase in $\mathrm{N}$ retention during late pregnancy (Faulkner, 1983) and probably also in the NA pool. That would lead to an increase in endogenous losses, assuming the rates of NA turnover are similar in all tissues. This increase might have been 
masked by the high residual variation recorded in the present experiment. However, if pregnancy brings about an improvement in the efficiency of tissue NA turnover, it would explain the lack of response to changes in the physiological state. The significant decrease in urinary hypoxanthine excretion, as major salvageable PD (Hitchings, 1978) in late pregnancy, is in accordance with this suggestion.

On the other hand, only urinary PD excretion was measured and the possibility of alternative routes of purine loss during pregnancy might be considered. From the commencement of foetal renal function, amniotic fluid acts as a waste pool (Pitkin, 1974; Seeds, 1974) in which the differential rates of foetal excretion and maternal absorption produce a storage of several catabolites like creatinine, uric acid (Free \& Free, 1974) and possibly all urinary PD and pyrimidine derivatives. Storage of these compounds in amniotic fluid may be a factor affecting the relationship between purine turnover and urinary losses during pregnancy.

\section{Endogenous pseudouridine excretion}

We have been searching for a non-invasive method to study RNA turnover, in order to investigate the significance of the variations in this process on urinary excretion of PD and pyrimidine derivatives. Pseudouridine is a modified pyrimidine-derivative constituent of $t$ RNA (2-9 residues/molecule) and r-RNA (252 residues/molecule; Sander et al. 1986b). Like every modified nucleoside pseudouridine is not incorporated into RNA (Borek et al. 1977; Gehrke et al. 1979), being excreted in urine during RNA turnover without possible further metabolism (Weissman et al. 1962). If it is assumed that the RNA chain contains less than $1 \%$ of total nucleosides as pseudouridine (Weissman et al. 1962), the high urinary excretion recorded $\left(36.0\right.$ (SE 2.04) $\mu \mathrm{mol} / \mathrm{kg} \mathrm{W}^{0.75}$ per d), about $20 \%$ of total purine excretion, confirms the organic inability to re-utilize this compound and, hence, its potential value as a RNA-turnover marker. The extent of pseudouridine losses $\left(36.0 \mu \mathrm{mol} / \mathrm{kg} \mathrm{W}^{0.75}\right.$ per $\mathrm{d}$ or $3.4 \mathrm{~mol} / 100 \mathrm{~mol}$ creatinine) is consistent with observations reported by Weissman et al. (1962) in mice $\left(28.4 \mu \mathrm{mol} / \mathrm{kg} \mathrm{W}^{0.75}\right.$ per d), and Puchala et al. (1993) in cows (20.5 $\mu \mathrm{mol} / \mathrm{kg} \mathrm{W}^{0.75}$ per d) and sheep $\left(20.3 \mu \mathrm{mol} / \mathrm{kg} \mathrm{W}^{0.75}\right.$ per d), although these values were consistently higher than those reported for children $\left(15 \cdot 2 \mu \mathrm{mol} / \mathrm{kg} \mathrm{W}^{0.75}\right.$ per d; Schöch et al. 1982) or adults (7-10.4 $\mu \mathrm{mol} / \mathrm{kg} \mathrm{W}^{0.75}$ per d; Borek \& Kerr, 1972).

The fact that in the present experiment animals were fed on a NA-free diet could explain the differences between our findings and those recorded in normally-fed animals. However, Puchala et al. (1993) demonstrated that urinary pseudouridine excretion is not affected by duodenal NA supply. Nevertheless, it is difficult to explain the wide variation between studies, assuming that for mammals both pseudouridine distribution and turnover rate are similar (Khan et al. 1978). However, significant differences associated with body development have been reported in the literature (Trisch et al. 1979; Sander et al. 1986 a; Puchala et al. 1993) and this may help to explain the variation discussed previously.

The authors are not familiar with any findings on urinary excretion of modified purine or pyrimidine residues in pregnant animals, but the trend towards increased pseudouridine excretion in pregnant $v$. non-pregnant sows $(P=0.097$, Table 2$)$ seems to reflect a higher rate of protein synthesis and NA turnover in late pregnancy, although further studies are needed to elucidate this possibility.

\section{Conclusion}

It is concluded that pregnancy did not affect endogenous PD excretion in sows. Thus, equations developed previously for non-pregnant animals (Balcells et al. 1991) to estimate the duodenal flow of purines from measurements of urinary PD excretion would not appear invalid when extended for use with pregnant animals. 
The authors are grateful to Dr Fondevila M. for his critical review of this manuscript. They also thank J. C. E. Surra for analytical assistance. This work has been supported by the CICYT Project Gan 91-1050-C02-01.

\section{REFERENCES}

al-Khalidi, U. A.S. \& Chaglassian, T. H. (1965). The species distribution of xanthine oxidase. Biochemical Journal 97, 318-320.

Agricultural Research Council (1981). The Nutrient Requirements of Pigs. Slough: Commonwealth Agricultural Bureaux

Balcells, J., Guada, J. A., Castrillo, C. \& Gasa, J. (1991). Urinary excretion of allantoin and allantoin precursors by sheep after different rates of purine infusion into the duodenum. Journal of Agricultural Science, Cambridge 116, 309-317.

Balcells, J., Guada, J. A., Castrillo, C. \& Gasa, J. (1993). Rumen digestion and urinary excretion of purine derivatives in response to urea supplementation of sodium-treated straw fed to sheep. British Journal of Nutrition 69, 721-732.

Balcells, J., Guada, J. A., Peiró, J. M. \& Parker, D. S. (1992). Simultaneous determination of allantoin and oxypurines in biological fluids by high-performance liquid chromatography. Journal of Chromatography $\mathbf{5 7 5}$, 153-157.

BMDP (1990). In Statistical Software Manual, [W. J. Dixon, editor]. Berkeley, Los Angeles and Oxford: University of California Press.

Borek, E., Baliga, B. S., Gehrke, Ch. W., Kuo, C. W., Belman, S., Troll, W. \& Waalkes, T. P. (1977). High turnover rate of transfer RNA in tumor tissue. Cancer Research 37, 3362-3366.

Borek, E. \& Kerr, S. J. (1972). Atypical transfer RNA's and their origin in neoplastic cells. Advances in Cancer Research 16, 163-190.

Chen, X. B. (1989). Excretion of purine derivatives by sheep and cattle and its use for the estimation of absorbed microbial protein. PhD Thesis, University of Aberdeen.

Chen, X. B., Hovell, F. D. DeB., Ørskov, E. R. \& Brown, D. S. (1990a). Excretion of purine derivatives by ruminants: effect of exogenous nucleic acid supply on purine derivative excretion by sheep. British Journal of Nutrition 63, 131-142.

Chen, X. B., Ørskov, E. R. \& Hovell, F. D. DeB. (1990b). Excretion of purine derivatives by ruminants: endogenous excretion, differences between cattle and sheep. British Journal of Nutrition 63, 121-129.

Condon, R. J., Hall, G. \& Hatfield, E. E. (1970). Metabolism of abomasally infused ${ }^{14} \mathrm{C}$ labeled ribonucleic acid, adenine, uracil, and glycine. Journal of Animal Science 31, 1037-1038.

Faulkner, A. (1983). Foetal and neonatal metabolism. In Nutritional Physiology of Farm Animals. 1st ed., pp. 203-207 [J. A. F. Rook and P. C. Thomas, editors]. New York: Longman Inc.

Folin, O., Berglund, H. \& Derick, C. (1924). The uric acid problem. An experimental study on animals and man, including gouty subjects. Journal of Biological Chemistry 60, 361 479

Free, A. H. \& Free, H. M. (1974). Laboratory interrelations of amniotic fluid and urine. In Current Topics in Clinical Chemistry, vol. 1. Amniotic Fluid: Physiology, Biochemistry and Clinical Chemistry, pp. 37-46 [S. Natelson, A. Scommegna and M. B. Epstein, editors]. New York and London: John Wiley and Sons.

Fujihara, T., Ørskov, E. R., Reeds, P. J. \& Kyle, D. J. (1987). The effect of protein infusion on urinary excretion of purine derivatives in ruminants nourished by intragastric nutrition. Journal of Agricultural Science, Cambridge 109, 7-12.

Fujihara, T., Chen, X. B., Ørskov, E. R. \& Hovell, F. D. (1988). The possible use of purine derivatives in urine to estimate rumen microbial protein production. In Proceedings of 5th International Symposium on Protein Metabolism and Nutrition. European Association of Animal Production Publication no. 35, pp. 17-18. [W. Browen, editor]. Rostock, Germany: Wilhelm-Pieck University of Rostock.

Gehrke, C. W., Kuo, K. C., Waalkes, T. P. \& Borek, E. (1979). Patterns of urinary excretion of modified nucleosides. Cancer Research 39, 1150-1153.

Giesecke, D., Stangassinger, M. \& Tiemeyer, W. (1984). Nucleic acid digestion and urinary purine metabolites in sheep nourished by intragastric infusions. Canadian Journal of Animal Science 64, Suppl., 144-145.

Greife, H. A. (1980). Nitrogen utilisation of microbial nucleic acids in the growing rat. In Proceedings of the $3 r d$ European Association of Animal Production Symposium on Protein Metabolism and Nutrition. European Association of Animal Production Publication no. 27, pp. 159-167 [H. J. Oslage and K. Rohr, editors]. Braunschweig, Germany: Institute of Animal Nutrition.

Hitchings, G. H. (1978). Uric acid: chemistry and synthesis. In Uric Acid, pp. 1-20 [W. N. Kelly and J. M. Weiner, editors]. Berlin, Heidelberg and New York: Springer-Verlag.

Khan, M. S. N., Salim, M. \& Maden, B. E. H. (1978). Extensive homologies between the methylated nucleotide sequences in several vertebrate ribosomal ribonucleic acids. Biochemical Journal 169, 531-542.

Lindberg, J. E. (1991). Nitrogen and purine metabolism in preruminant and ruminant goat kids given increasing amounts of ribonucleic acids. Animal Feed Science and Technology 35, 213-226.

Lindberg, J. E. \& Jacobsson, K.-G. (1990). Nitrogen and purine metabolism at varying energy and protein supplies in sheep sustained on intragastric infusion. British Journal of Nutrition 64, 359-370. 
Martin, S. M., Balcells, J., Guada, J. A. \& Castrillo, C. (1993). Endogenous purine and pyrimidine derivative excretion in pregnant sows. Proceedings of the Nutrition Society 52, 277 A.

Murray, A. W. (1971). The biological significance of purine salvage. Annual Review of Biochemistry 40, 811-826.

Ørskov, E. R., Grubb, D. A., Wenham, G. \& Corrigall, W. (1979). The sustenance of growing and fattening ruminants by intragastric infusion of volatile fatty acid and protein. British Journal of Nutrition 41, 553-558.

Pitkin, R. M. (1974). Changes in osmolality, nonprotein nitrogen, and bilirubin in amniotic fluid during the course of pregnancy. In Current Topics in Clinical Chemistry, vol. 1. Amniotic Fluid: Physiology, Biochemistry and Clinical Chemistry, pp. 81-94 [S. Natelson, A. Scommegna and M. B. Epstein, editors]. New York and London: John Wiley and Sons.

Puchala, R., Shelford, J. A., Barej, W., Kulasek, G. W., Piór, H., Keyserlingk, M. V. \& Makoni, N. (1993). Urinary excretion of pseudouridine and purine metabolites in ruminants. Journal of Animal Physiology and Animal Nutrition 69, 186-193.

Razzaque, M. A., Topps, J. H., Kay, R. N. B. \& Brockway, J. M. (1981). Metabolism of the nucleic acids of rumen bacteria by preruminant and ruminant lambs. British Journal of Nutrition 45, 517-527.

Roth, F. X. \& Kirchgessner, M. (1979). Utilisation of alimentary ribonucleic acid in calves, N-metabolism. Archiv für Tierernährung 29, 275-283.

Sander, G., Hülsemann, J., Topp, H., Heller-Schöch, G. \& Schöch, G. (1986a). Protein and RNA turnover in preterm infants and adults: A comparison based on urinary excretion of 3-methylhistidine and of modified oneway RNA catabolites. Annals of Nutrition and Metabolism 30, 137-142.

Sander, G., Topp, H., Heller-Schöch, G., Wieland, J. \& Schöch, G. (1986b). Ribonucleic acid turnover in man: RNA catabolites in urine as measure for the metabolism of each of the three major species of RNA. Clinical Science 71, 367-374.

Schöch, G., Heller-Schöch, G., Müller, J., Heddrich, M. \& Grüttner, R. (1982). Determination of RNA metabolism as indicator of nutritional status. Klinische Pädiatrie 194, 317-319.

Seeds, A. E. (1974). Dynamics of amniotic fluid. In Current Topics in Clinical Chemistry, vol. 1. Amniotic Fluid: Physiology, Biochemistry and Clinical Chemistry, pp. 23-36 [S. Natelson, A. Scommegna and M. B. Epstein, editors]. New York and London: John Wiley and Sons.

Smith, R. C., Moussa, N. M. \& Hawkins, G. E. (1974). Utilization of the nucleic acids of Escherichia coli and rumen bacteria by sheep. British Journal of Nutrition 32, 529-537.

Steel, R. G. D. \& Torrie, J. H. (1980). Principles and Procedures of Statistics, 2nd ed. New York: McGraw-Hill.

Technicon Instruments Co. Inc. (1989). Creatinine Technicon Method no. SM4-0141F89. Tarrytown, New York: Technicon Instruments Co. Inc.

Tritsch, G. L., Luch, J. M., Evans, J. T. \& Mittelman, A. (1979). Age dependence of human urinary pseudouridine excretion. Biochemical Medicine 22, 387-390.

Waterlow, J. C. (1984). Protein turnover with special reference to man. Quarterly Journal of Experimental Physiology 69, 409-438.

Weissman, S., Eisen, A. Z., Lewis, M., Karon, M. \& Clark, P. (1962). Pseudouridine metabolism. III. Studies with isotopically labeled pseudouridine. Journal of Laboratorial and Clinical Medicine 60, 40-47.

Zöllner, N. (1982). Purine and pyrimidine metabolism. Proceedings of the Nutrition Society 41, 329-342. 